\title{
Review Article \\ Hydrogen Sulfide: Emerging Role in Bladder, Kidney, and Prostate Malignancies
}

\author{
Masoud Akbari $\mathbb{D}^{1,2}$ Emrullah Sogutdelen $\mathbb{D}^{1,2,3}$ Smriti Juriasingani $\mathbb{D}^{1,2}$ \\ and Alp Sener iD $1,2,3,4$ \\ ${ }^{1}$ Department of Microbiology \& Immunology, Schulich School of Medicine \& Dentistry, University of Western Ontario, \\ Dental Sciences Building, Rm 3014, London, Ontario, Canada N6A 5C1 \\ ${ }^{2}$ Matthew Mailing Center for Translational Transplant Studies, University Hospital, London Health Sciences Center, \\ 339 Windemere Road, London, Ontario, Canada N6A 5A5 \\ ${ }^{3}$ Department of Surgery, Schulich School of Medicine \& Dentistry, St. Joseph's Health Care London, PO BOX 5777, STN B, London, \\ Ontario, Canada N6A 4V2 \\ ${ }^{4}$ Multi-Organ Transplant Program, University Hospital, London Health Sciences Centre, 339 Windemere Road, London, Ontario, \\ Canada N6A 5A5
}

Correspondence should be addressed to Alp Sener; alp.sener@lhsc.on.ca

Received 18 April 2019; Revised 22 July 2019; Accepted 30 September 2019; Published 3 November 2019

Guest Editor: Jayeeta Ghose

Copyright ( 2019 Masoud Akbari et al. This is an open access article distributed under the Creative Commons Attribution License, which permits unrestricted use, distribution, and reproduction in any medium, provided the original work is properly cited.

\begin{abstract}
Hydrogen sulfide $\left(\mathrm{H}_{2} \mathrm{~S}\right)$ is the latest member of the gasotransmitter family and known to play essential roles in cancer pathophysiology. $\mathrm{H}_{2} \mathrm{~S}$ is produced endogenously and can be administered exogenously. Recent studies showed that $\mathrm{H}_{2} \mathrm{~S}$ in cancers has both pro- and antitumor roles. Understanding the difference in the expression and localization of tissue-specific $\mathrm{H}_{2} \mathrm{~S}$-producing enzymes in healthy and cancer tissues allows us to develop tools for cancer diagnosis and treatment. Urological malignancies are some of the most common cancers in both men and women, and their early detection is vital since advanced cancers are recurrent, metastatic, and often resistant to treatment. This review summarizes the roles of $\mathrm{H}_{2} \mathrm{~S}$ in cancer and looks at current studies investigating $\mathrm{H}_{2} \mathrm{~S}$ activity and expression of $\mathrm{H}_{2} \mathrm{~S}$-producing enzymes in urinary cancers. We specifically focused on urothelial carcinoma, renal cell carcinoma, and prostate cancer, as they form the majority of newly diagnosed urinary cancers. Recent studies show that besides the physiological activity of $\mathrm{H}_{2} \mathrm{~S}$ in cancer cells, there are patterns between the development and prognosis of urinary cancers and the expression of $\mathrm{H}_{2} \mathrm{~S}$-producing enzymes and indirectly the $\mathrm{H}_{2} \mathrm{~S}$ levels. Though controversial and not completely understood, studying the expression of $\mathrm{H}_{2} \mathrm{~S}$-producing enzymes in cancer tissue may represent an avenue for novel diagnostic and therapeutic strategies for addressing urological malignancies.
\end{abstract}

\section{Hydrogen Sulfide}

For several centuries, hydrogen sulfide $\left(\mathrm{H}_{2} \mathrm{~S}\right)$ was known as a pollutant, but now its physiological and pathophysiological processes are well known. $\mathrm{H}_{2} \mathrm{~S}$ is widely recognized as the third endogenous gasotransmitter after carbon monoxide (CO) and nitric oxide (NO) in mammals and some other species, with similar pathophysiological characteristics $[1,2] . \mathrm{H}_{2} \mathrm{~S}$ is synthesized endogenously by reverse transsulfidation and oxidation of cysteine [3-6], by three tissue-specific enzymes: cystathionine $\beta$-synthase (CBS), cystathionine $\gamma$-lyase (CSE), and 3-mercaptopyruvate sulfurtransferase (3-MPST) [3, 4, 7-11]. All of them are cytosolic [12-14], but 3-MPST is also localized in the mitochondria $[3,12,15]$. Upon synthesis in different cell compartments such as in the mitochondria, a free form of $\mathrm{H}_{2} \mathrm{~S}$ can be released into the cytoplasm or be stored inside the cell as bound sulfane sulfur for subsequent release of $\mathrm{H}_{2} \mathrm{~S}$ (Figure 1) $[16,17]$.

Endogenous $\mathrm{H}_{2} \mathrm{~S}$ is a key signaling molecule in humans and other mammals. It has been detected in many organs, and it is involved in the various physiological and 




FIGURE 1: Synthesis, storage, degradation, and activity of $\mathrm{H}_{2} \mathrm{~S}$, especially in urinary cancers. $\mathrm{H}_{2} \mathrm{~S}$ has roles in different pathways of urinary cancers such as signaling or ion channel. Abbreviations: CBS: cystathionine $\beta$-synthase, CSE: cystathionine $\gamma$-lyase, 3-MPST: 3-mercaptopyruvate sulfurtransferase, Stat3/Nmpt: signal transducer and activator of transcription 3/nicotinamide phosphoribosyltransferase, HSP60: heat shock protein 60, PI3K/AKT: phosphatidylinositol 3-kinase, UC: urothelial carcinoma, RCC: renal cell cancer, PCa: prostate cancer.

pathophysiological processes [12, 18-20]. $\mathrm{H}_{2} \mathrm{~S}$ is known to play a role in redox homeostasis and antioxidant responses [21-23], angiogenesis [24-30], vasodilation [31], regulation of synaptic transmission [32], inflammatory responses [33], glucose metabolism [34, 35], ATP production [36], and apoptosis and cell proliferation $[23,31,37-42]$. The role that $\mathrm{H}_{2} \mathrm{~S}$ plays in these processes appears to be concentration dependent. The concentration of free $\mathrm{H}_{2} \mathrm{~S}$ in plasma could not be measured in a proper way because it is affected by environmental factors such as $\mathrm{pH}$ [43], but an initial study utilizing the methylene blue method reported to be between 50 and160 $\mu \mathrm{M}$ in human and rat serum [44]. However, the recent studies are suggesting that the endogenous concentration of $\mathrm{H}_{2} \mathrm{~S}$ is much less and is between $10 \mathrm{nM}$ and $3 \mu \mathrm{M}$ $[45,46]$. As $\mathrm{H}_{2} \mathrm{~S}$ has a dual effect, at lower concentrations, it has a physiological function in different tissues, whereas at higher concentrations, $\mathrm{H}_{2} \mathrm{~S}$ exerts its toxic effects by reversibly blocking of cytochrome $\mathrm{C}$ oxidase and inhibiting the electron transport chain in the mitochondria [47-49]. The catabolism of $\mathrm{H}_{2} \mathrm{~S}$ occurs mainly in the mitochondria by enzymatic pathways such as oxidoreductases and sulfurtransferase that break it into thiosulfate and sulfate. Moreover, oxidation of $\mathrm{H}_{2} \mathrm{~S}$ reduces the $\mathrm{FAD}$ prosthetic group, which uses ubiquinone $(\mathrm{Q})$ as an electron acceptor, in electron transport chain which has a role in ATP production (Figure 1) [15, 36, 50-52]. However, under hypoxic conditions, oxidation of $\mathrm{H}_{2} \mathrm{~S}$ in the mitochondria reduces, allowing $\mathrm{H}_{2} \mathrm{~S}$ to accumulate and function as an oxygen sensor [53, 54]. $\mathrm{H}_{2} \mathrm{~S}$ accumulation during hypoxia helps to maintain cell function by upregulating anaerobic metabolic pathways like glycolysis [55] and other cytoprotective pathways [56]. $\mathrm{H}_{2} \mathrm{~S}$ also promotes restoration of the tissue oxygen supply by relaxation of vascular smooth muscles (vasodilation) and also stimulation of endothelial cell proliferation and migration (angiogenesis) [24, 57]. Beside the mitochondrial sulfide oxidation [58], $\mathrm{H}_{2} \mathrm{~S}$ can be oxidized and catabolized by two other minor pathways $[9,59]$. The first pathway is the methylation of $\mathrm{H}_{2} \mathrm{~S}$ by thiol S-methyltransferase in the cytosol [60], and the second pathway is an interaction between $\mathrm{H}_{2} \mathrm{~S}$ and methemoglobin that leads to the production of sulfhemoglobin and polysulfides, which can be used as a biomarker for plasma $\mathrm{H}_{2} \mathrm{~S}$ levels $[61,62]$.

\section{2. $\mathrm{H}_{2} \mathrm{~S}$ in Cancer}

Several studies have shown that $\mathrm{H}_{2} \mathrm{~S}$ and its synthases are associated with the pathophysiology of tumors [20, 49, 63-66]. It has been shown that $\mathrm{H}_{2} \mathrm{~S}$ can modulate oxidative stress, interact with free radicals, and activate tumorigenic pathways [39, 61]. Several studies investigated the role and presence of $\mathrm{H}_{2} \mathrm{~S}$ in tumors. The expression of $\mathrm{H}_{2} \mathrm{~S}$-producing enzymes (CBS, CSE, and 3-MPST) has been studied in various cancers including liver, colon, ovarian, breast, gastric, lung, oral squamous cell carcinoma, and melanoma [42, 49, 67-74]. However, the role and effect of $\mathrm{H}_{2} \mathrm{~S}$ on tumor biology, development, and progression are controversial [75-78]. Previous reviews have adequately summarized that $\mathrm{H}_{2} \mathrm{~S}$ can have pro- or anticancerous effects based on the type of tumor and the involved organ $[23,67]$. It is reported that endogenous $\mathrm{H}_{2} \mathrm{~S}$ can have procancerous effects and help the survival of tumors by stimulating angiogenesis along with promoting cell proliferation, metastasis, and drug resistance [32, 49, 67, 79-81]. The anticancerous effects of exogenous $\mathrm{H}_{2} \mathrm{~S}$ administration have been reported for several human cancers $[82,83]$. Endogenous $\mathrm{H}_{2} \mathrm{~S}$ can be employed as a biomarker for cancer imaging in mice and for differentiating cancer cells [84, 85]. Several pathways, such as inhibition of proliferation, induction of apoptosis, reduction of NF- $\kappa \mathrm{B}$ levels, DNA damage, and modification of the cell cycle, are involved in the anticancer activity of $\mathrm{H}_{2} \mathrm{~S}[27,29,82,86]$.

Similar to endogenous $\mathrm{H}_{2} \mathrm{~S}$, the effect of exogenous $\mathrm{H}_{2} \mathrm{~S}$ treatment also shows a biphasic dose-dependent response on cancer cells as it does in healthy tissues whereby low concentrations of $\mathrm{H}_{2} \mathrm{~S}$ exhibit a procancerous effect and high concentrations exert an anticancerous effect $[65,67,82,83$, 87]. The hypoxic environment of solid tumors [88] leads to 
a higher level of endogenous $\mathrm{H}_{2} \mathrm{~S}$ synthesis $[89,90]$ and reduces the sulfide detoxification ability of the mitochondria [54, 91], which makes tumors more susceptible to $\mathrm{H}_{2} \mathrm{~S}$ toxicity. However, Malagrinò et al. showed that in hypoxic conditions, the activity of the mitochondrial sulfide-oxidizing pathway of quinone oxidoreductase (SQR) adaptively increased and improved the $\mathrm{H}_{2} \mathrm{~S}$ detoxification of mitochondria [92].

The direct quantification of $\mathrm{H}_{2} \mathrm{~S}$ in tissue samples is a challenge since it has a very short half-life [93]; one study used live fluorescent imaging techniques to visualize the $\mathrm{H}_{2} \mathrm{~S}$ in live cells directly [90]. However, in general, the expression level of $\mathrm{H}_{2} \mathrm{~S}$-producing enzymes can be used to indirectly show the correlation between $\mathrm{H}_{2} \mathrm{~S}$ and its effects on healthy tissues and tumors $[49,80]$. Increased levels of $\mathrm{H}_{2} \mathrm{~S}$ and the upregulation of one or more $\mathrm{H}_{2} \mathrm{~S}$-synthesizing enzymes in comparison to healthy tissues have been reported in several tumors $[49,71,72,80,94,95]$. It is also quite interesting that these three enzymes are expressed differently according to the type of cancer [67] and hence lend themselves as potential new targets for therapy.

\section{3. $\mathrm{H}_{2} \mathrm{~S}$ in Urinary Cancers}

Urinary cancers specifically kidney, urothelial, and prostate are relatively common in developed countries. Prostate cancer [96] is the second most commonly diagnosed cancer in men, and urothelial carcinomas (UCs) [97] are the fourth most common tumors both in men and in women. Kidney cancers are highly lethal, and their incidence is increasing incidentally by the common use of diagnostic tools. It is estimated that more than 300,000 new cases of urinary cancers and 33,429 deaths (excluding prostate cancer) will occur in 2019 in the United States [97]. As such, the role of $\mathrm{H}_{2} \mathrm{~S}$ and the differential expression of $\mathrm{H}_{2} \mathrm{~S}$-producing enzymes in urinary cancers are of interest, and this review is aimed at summarizing recent evidence on this subject in the context of three common urinary cancers: urothelial cancer, renal cell carcinoma, and prostate cancer.

3.1. Urothelial Cancer. Urothelial carcinoma can be located in the lower (bladder and urethra) or the upper (pyelocaliceal cavities and ureter) urinary tract. Bladder tumors account for 90-95\% of UCs and are the most common urinary tract malignancy. Sixty percent of upper tract urothelial cancers are invasive at diagnosis compared with $15-25 \%$ of bladder tumors [98]. The high recurrence rate and potential of metastasis are two critical characteristics of bladder cancer [99, 100]. Environmental (smoking and exposure to chemical-occupational toxins) and genetic factors all play a role in the etiology of bladder cancer, as does gender since it is more frequent in men older than 65 years of age [101].

Several studies have highlighted the importance of abnormal redox and cellular signaling in the incidence of bladder cancer [102]. Various reports suggest that alterations in $\mathrm{H}_{2} \mathrm{~S}$ synthesis pathways may increase the risk of bladder cancer $[103,104]$, suggesting that the modification of these pathways may lead to the development of novel diagnostic and therapeutic approaches for urological cancers [4].
$\mathrm{H}_{2} \mathrm{~S}$ has been detected in bladder homogenates of trout, mice, pigs, rats, and humans [105-109]. In humans, $\mathrm{H}_{2} \mathrm{~S}$ is involved in the control of bladder tone homeostasis [110], as it has previously been shown that exogenous $\mathrm{H}_{2} \mathrm{~S}$ or its substrate, L-cysteine, could decrease the tone of human and rat bladder strips in a dose-dependent manner [107, 108]. All of the $\mathrm{H}_{2} \mathrm{~S}$-producing enzymes are also found in rat and human bladders, whereas in the mouse, only CSE could be detected [107-109]. The expression of these enzymes in human bladder cancer tissues and cell lines has been investigated. A recent study examined the expression of $\mathrm{H}_{2} \mathrm{~S}$-producing enzymes in human bladder cancer tissues and compared them to healthy ones. They compared 94 human bladder cancer at different stages/grades and 20 human healthy bladder tissues in term of $\mathrm{H}_{2} \mathrm{~S}$ content as well as the $\mathrm{H}_{2} \mathrm{~S}$ synthases while attempting to find a correlation between the expression of $\mathrm{H}_{2} \mathrm{~S}$-producing enzymes and the malignant progression of bladder cancer. They showed that $\mathrm{H}_{2} \mathrm{~S}$ content, as well as the expression of CBS, CSE, and 3-MPST, was higher in bladder cancer than in healthy samples. More interestingly, the enzyme expression of all three enzymes was correlated to different stages of bladder cancer. They suggested that this correlation between the malignancy and the expression of $\mathrm{H}_{2} \mathrm{~S}$ enzymes could lead to novel diagnosis and treatment applications [111]. Another recent study also showed, both in vitro and in vivo models, that apoptosis of bladder cancer cell lines or tissues with cisplatin was enhanced after the inhibition of $\mathrm{H}_{2} \mathrm{~S}$ production by propargylglycine (PAG) [23] and was inhibited upon adding the exogenous $\mathrm{H}_{2} \mathrm{~S}$. These authors suggested the activation of the Erk1/2 signaling pathway and the blockage of mitochondrial apoptosis as the possible mechanisms behind their results [112].

Exogenous $\mathrm{H}_{2} \mathrm{~S}$ administration has also been shown to affect bladder cancer cell lines. The in vitro treatment of the bladder cancer cell line EJ with NaHS enhances cell proliferation and the invasion ability of the cells [113]. Interestingly, these authors also found that the expression of matrix metalloproteinases (MMP) 2 and 9, which are essential for the digestion of collagen IV, was increased in a dose-dependent manner upon the treatment of bladder cancer cells with NaHS. These two enzymes are essential in hydrolyzing the extracellular matrix during the invasion; therefore, $\mathrm{H}_{2} \mathrm{~S}$ might be necessary for the invasion of bladder cancer [113]. In addition, nicotinamide phosphoribosyltransferase (Nampt) is the rate-limiting step of nicotinamide adenine dinucleotide synthesis also increased in some cancers [114]. The signal transducer and activator of transcription 3 (Stat3) is one of the cell signaling molecules of the $\mathrm{H}_{2} \mathrm{~S}$, and its activation induces Nampt protein expression via a positive feedback loop. A recent study showed that UC is immunoreactive for the enzymatically active phosphorStat3 signal transduction pathway and increased the Nampt and CBS protein expression [115]. Overall, bladder cancer appears to present with higher $\mathrm{H}_{2} \mathrm{~S}$ levels in cancer tissue homogenates and increased the expression of $\mathrm{H}_{2} \mathrm{~S}$ producing enzymes, which suggests that $\mathrm{H}_{2} \mathrm{~S}$ may be essential for bladder cancer progression and growth, especially in the context of the induction of cell proliferation, 
inhibition of apoptosis, and facilitation of tissue invasion. Further research is needed to establish consistent expression patterns and other cellular mechanisms for potential diagnostic and therapeutic approaches.

3.2. Renal Cell Carcinoma. Renal cell carcinoma (RCC) represents $2-3 \%$ of all cancers with the highest incidence in Western countries. The incidence varies globally, with the highest rates in developed countries such as North America and Europe and the lowest rates in Asia and Africa [116]. Over 300,000 men and women are diagnosed with kidney cancer around the world each year, and approximately 150,000 patients will die of the disease [96].

Clear cell renal cell carcinoma (ccRCC), papillary carcinoma, and chromophobe are the common subtypes of RCC [117], although ccRCC accounts for $80 \%$ of all RCCs [118]. Because of the lack of early warning signs and the absence of screening tests for people with a higher risk of kidney cancer, more than $30 \%$ of patients are at the metastatic stage at the time of diagnosis [119]. Metastatic RCC is highly resistant to systemic chemotherapy and radiation therapy [120,121].

Inactivation of the Von Hippel-Lindau (VHL) tumor suppressor, which is responsible for the degradation of hypoxia-inducible factor alpha subunits (HIF-1/2 $\alpha$ ) during normoxia, occurs in $90 \%$ of ccRCC cases $[122,123]$. As a result, HIF- $1 / 2 \alpha$ subunits are not degraded under normoxic conditions in RCC cells, and the cells become pseudohypoxic [118]. The Warburg effect, which refers to a shift from mitochondrial respiration to glycolysis and production of lactate [124], enhances tumor growth and metastasis in RCC [125]. Using live cell imaging, Sonke et al. have previously shown that VHL-deficient ccRCC cell lines (769-P and 786-O) have significantly higher $\mathrm{H}_{2} \mathrm{~S}$ levels in comparison to ccRCC cells with wild-type VHL (Caki-1). They also showed that the inhibition of $\mathrm{H}_{2} \mathrm{~S}$-producing enzymes by hydroxylamine (HA), which is an inhibitor of CBS and CSE, and PAG, an inhibitor of CSE, significantly decreases the $\mathrm{H}_{2} \mathrm{~S}$ levels in VHL-deficient ccRCC cell lines and subsequently inhibits their proliferation and metabolic activity. Moreover, this inhibition of $\mathrm{H}_{2} \mathrm{~S}$ synthesis in VHL-deficient ccRCC cell lines results in a twofold reduction in cell survival rate in comparison to untreated cells. Another key finding from this work was that systemic inhibition of $\mathrm{H}_{2} \mathrm{~S}$ enzymes by $\mathrm{HA}$ administration in xenografted ccRCC in chicken embryos inhibited their vascularization and the subsequent growth of xenografts, which supports the known angiogenic activity of $\mathrm{H}_{2} \mathrm{~S}$ [79].

Two more recent studies have also evaluated the expression of $\mathrm{H}_{2} \mathrm{~S}$ enzymes in ccRCC. Shackelford et al. compared the expression of CBS in between human benign and Fuhrman grade I-IV ccRCC tissues by using tissue microarray and immunohistochemistry. They showed that CBS expressed weakly in benign tissues and even weaker in Fuhrman grade I ccRCC; however, its expression increased with increasing Fuhrman grades, and CBS expression was the highest in Fuhrman grade IV ccRCC samples [95]. Moreover, the Nmpt expression was correlated with CBS in increasing grade of tumors. Therefore, $\mathrm{H}_{2} \mathrm{~S}$ may play a contributory role in the progression of RCC [95]. Breza et al. also investigated the expression of $\mathrm{H}_{2} \mathrm{~S}$-producing enzymes in 21 human ccRCC tissues and compared it to the normal/healthy portion of the same kidney sample using microarray and immunohistochemistry. They found that $66 \%$ of ccRCC tissue samples exhibited stable expression of CBS, and the remaining samples showed downregulation. CSE was downregulated in all samples except in three where it was unchanged. The expression of 3-MPST was decreased by $70 \%$ of ccRCC samples and remained unchanged in $30 \%$ of ccRCC samples [121]. These data suggest that the expression of $\mathrm{H}_{2} \mathrm{~S}$ enzymes is heterogeneously regulated in ccRCC. The contradiction between results might be attributed to Shackelford et al. not comparing benign/malignant tissues from the same patient. Breza et al. also showed that, upon induction of apoptosis, the expression of these enzymes was upregulated in the RCC4 cell line (human RCC cell line) and silencing of CBS and CSE expression made the cells resistant to apoptosis [121]. It is possible that endogenous $\mathrm{H}_{2} \mathrm{~S}$ induces apoptosis in ccRCC as it was previously reported with exogenous administration [126-130]. The mechanisms behind RCC progression are not well understood, but it is suggested that knocking down of heat shock protein 60 (HSP60) increases the epithelial to mesenchymal transition and enhances invasion and also disturbs the respiratory complex 1 and triggers reactive oxygen molecules and then DNA methylation for further tumorigenesis [131-133]. Tang et al. results supported that suggestion and showed that HSP60 expression is lower in ccRCC tissues compared to pericancerous tissues [134]. The PI3K/AKT pathway is another important pathway in RCC progression, and it is reported that exogenous $\mathrm{H}_{2} \mathrm{~S}$ inhibits this pathway, and therefore, exogenous $\mathrm{H}_{2} \mathrm{~S}$ could be a novel targeted therapy of RCC $[135,136]$. Overall, the expression of $\mathrm{H}_{2} \mathrm{~S}$ enzymes could one day become a new tool for establishing prognosis in patients with RCC. However, further studies are necessary to elucidate the exact role of $\mathrm{H}_{2} \mathrm{~S}$ in RCC and to explain the contradictions between different studies.

3.3. Prostate Cancer. Prostate cancer (PCa) is the second most common cancer in men, with an estimated 1.1 million new cases worldwide in 2012, accounting for 15\% of all cancers diagnosed. The incidence of PCa varies widely between different geographical areas, highest in developed countries, mainly due to the use of prostate-specific antigen (PSA) testing and the aging of the population [96]. Surgery, radiotherapy, and androgen deprivation therapies are the primary treatment modalities that are effective, especially in the early stages of the disease [137]. Although a physical exam and the serum PSA test are commonly used to screen and detect for prostate cancer; their utility is ineffective in diagnosing early stages of prostate cancer.

The relationship between $\mathrm{H}_{2} \mathrm{~S}$ activity and prostate cancer has been reviewed previously [138]. The expression of $\mathrm{H}_{2} \mathrm{~S}$-producing enzymes was compared between cancerous and healthy prostate tissues $[108,139]$. Endogenous $\mathrm{H}_{2} \mathrm{~S}$ and all three enzymes (CBS, CSE, and 3-MPST) have been demonstrated in healthy and prostate cancer. CSE has been 
TABLE 1: Summary of $\mathrm{H}_{2} \mathrm{~S}$ and its producing enzymes in three common urinary cancers.

\begin{tabular}{ll}
\hline & $\mathrm{H}_{2} \mathrm{~S}$ highlights \\
\hline Urothelial & (i) Expressions of $\mathrm{H}_{2} \mathrm{~S}$ and its synthases are higher in cancer tissue [111]. \\
carcinoma & (ii) $\mathrm{H}_{2} \mathrm{~S}$ protects the bladder cancer against apoptosis [112]. \\
& (iii) $\mathrm{H}_{2} \mathrm{~S}$ increases the cell proliferation, invasion, and metastasis of bladder cancer [113]. \\
& (i) Enhanced expression of $\mathrm{H}_{2} \mathrm{~S}$ in ccRCC due to VHL deficiency improves the survival, growth, and metastasis [79]. \\
Renal cell carcinoma & (ii) Controversial reports about the comparative expression of $\mathrm{H}_{2} \mathrm{~S}$ enzymes [95, 121]. \\
& (iii) $\mathrm{H}_{2} \mathrm{~S}$ contributes to the induction of apoptosis in RCC [121]. \\
Prostate cancer & (i) $\mathrm{H}_{2} \mathrm{~S}$ enzymes are expressed in the prostate [107]. \\
& (ii) $\mathrm{CSE}$ is the main $\mathrm{H}_{2} \mathrm{~S}$-producing enzyme in the prostate [107, 139, 142]. \\
& (iii) CSE is downregulated in prostate cancer [140].
\end{tabular}

shown to have a higher expression in the smooth muscle layer of the prostate cancer samples [94]. However, in another study, they could not detect the expression of 3 MPST in both normal and cancerous prostate tissues, but they showed that CSE was significantly downregulated in prostate cancer, whereas CBS was not changed in each sample. This study also showed that antiandrogen-resistant prostate cancer cells express less CSE and have lower $\mathrm{H}_{2} \mathrm{~S}$ content in comparison to the parental cell line [140].

Moreover, new evidence suggests that $\mathrm{H}_{2} \mathrm{~S}$-releasing molecules could be effective in the treatment of chemotherapyresistant prostate cancers [141]. The stromal part of the prostate tissue and the stromal cell line showed average to high CSE expression [139]. In addition, both CBS and CSE are present in mouse prostate cancers, unrelated to androgen dependency, and in vitro work showed that CSE is the main contributor to $\mathrm{H}_{2} \mathrm{~S}$ production in prostate cancer cell lines (PC-3). The critical role of CSE was confirmed upon finding that aged CSE knockout mice have higher cell proliferation and significantly less $\mathrm{H}_{2} \mathrm{~S}$ production in the prostate [142]. Interestingly, the androgen-dependent prostate cell line showed the highest expression of CBS and CSE, and their expression was downregulated upon dihydrotestosterone treatment [139]. These data suggest that CSE may be a potential therapeutic target and diagnostic tool for prostate cancer.

As mentioned earlier, thiosulfate is the stable breakdown product of $\mathrm{H}_{2} \mathrm{~S}$ in the mitochondria that can be tracked in the urine. Therefore, the thiosulfate level in urine can be an indicator of exposure to $\mathrm{H}_{2} \mathrm{~S}$ or disruption in the breakdown process. Chwatko et al. investigated urinary thiosulfate levels amongst the malignant in comparison to benign prostate hyperplasia $(\mathrm{BPH})$ patients and healthy volunteers. They also found that the urine level of thiosulfate in malignant prostate cancer patients was 50 times higher than the healthy volunteers and five times higher than the BPH patients, and also, there was a positive correlation between the size of the prostate and the urine level of thiosulfate in comparison between the $\mathrm{BPH}$ and the control group [143]. In the nude mouse model of human prostate cancer, the plasma concentration of cysteine was significantly decreased after advanced tumor growth [144]. Contrary to these results, five years after prostatectomy, cysteine, homocysteine, and cystathionine were found to be higher in the urine of recurrent prostate cancer patients in comparison to recurrence-free patients [145].
Recent studies showed that methionine catabolism [146], and increased level of cystathionine [147] and sarcosine (N-methylglycine), a by-product of methionine catabolism [148], in urine correlated with prostate cancer stage. In addition, recent data suggest that neuroendocrine-like differentiation of prostate cancer (LNCaP) cells contributes to the androgen-independent growth [149, 150]. The expression and activity of CSE and CBS, in LNCaP cell, are much more than those in healthy prostatic epithelial cells [139]. The $\mathrm{H}_{2} \mathrm{~S}$ donors, NaHS and $\mathrm{Na}_{2} \mathrm{~S}$, further enhance the upregulated calcium channels in the LNCaP cells [151]. Overall, it appears that cysteine, homocysteine, cystathionine, and sarcosine could all potentially be biomarkers for prostate cancer.

\section{Conclusion}

Despite significant research efforts in recent years, the role of $\mathrm{H}_{2} \mathrm{~S}$ in the context of cancer pathophysiology remains controversial (Table 1). Several studies have partially elucidated the vital role of $\mathrm{H}_{2} \mathrm{~S}$ activity, which plays a different role in urological malignancies (Figure 1). Interestingly, the expression patterns of $\mathrm{H}_{2} \mathrm{~S}$-producing enzymes appear to be contradictory, depending upon the subtype of cancer, which was evaluated and in fact, may be tissue dependent. However, these studies, as mentioned earlier, lay the groundwork for future work that may lead to the development of new diagnostic tools for detecting urinary cancers in earlier stages. Moreover, pharmacological modulation of $\mathrm{H}_{2} \mathrm{~S}$ synthetic pathways and exogenous administration of donor molecules may one day provide us with additional therapeutic avenues in treating patients with urological malignancies.

\section{Conflicts of Interest}

The authors declare that there is no conflict of interest regarding the publication of this paper.

\section{References}

[1] P. Fagone, E. Mazzon, P. Bramanti, K. Bendtzen, and F. Nicoletti, "Gasotransmitters and the immune system: mode of action and novel therapeutic targets," European Journal of Pharmacology, vol. 834, pp. 92-102, 2018. 
[2] R. Wang, "Gasotransmitters: growing pains and joys," Trends in Biochemical Sciences, vol. 39, no. 5, pp. 227-232, 2014.

[3] H. Kimura, "Hydrogen sulfide: its production, release and functions," Amino Acids, vol. 41, no. 1, pp. 113-121, 2011.

[4] L. Li, P. Rose, and P. K. Moore, "Hydrogen sulfide and cell signaling," Annual Review of Pharmacology and Toxicology, vol. 51, no. 1, pp. 169-187, 2011.

[5] T. Ida, T. Sawa, H. Ihara et al., "Reactive cysteine persulfides and S-polythiolation regulate oxidative stress and redox signaling," Proceedings of the National Academy of Sciences of the United States of America, vol. 111, no. 21, pp. 7606-7611, 2014.

[6] P. K. Yadav, M. Martinov, V. Vitvitsky et al., "Biosynthesis and reactivity of cysteine persulfides in signaling," Journal of the American Chemical Society, vol. 138, no. 1, pp. 289299, 2016.

[7] O. Kabil and R. Banerjee, "Enzymology of $\mathrm{H}_{2} \mathrm{~S}$ biogenesis, decay and signaling," Antioxidants \& Redox Signaling, vol. 20, no. 5, pp. 770-782, 2014.

[8] K. R. Olson, " $\mathrm{H}_{2} \mathrm{~S}$ and polysulfide metabolism: conventional and unconventional pathways," Biochemical Pharmacology, vol. 149, pp. 77-90, 2018.

[9] A. Giuffrè and J. B. Vicente, "Hydrogen sulfide biochemistry and interplay with other gaseous mediators in mammalian physiology," Oxidative Medicine and Cellular Longevity, vol. 2018, Article ID 6290931, 31 pages, 2018.

[10] S. Pandey, "Hydrogen sulfide: a new node in the abscisic aciddependent guard cell signaling network?," Plant Physiology, vol. 166, no. 4, pp. 1680-1681, 2014.

[11] J. T. Hancock and M. Whiteman, "Hydrogen sulfide and cell signaling: team player or referee?," Plant Physiology and Biochemistry, vol. 78, pp. 37-42, 2014.

[12] R. Wang, "Physiological implications of hydrogen sulfide: a whiff exploration that blossomed," Physiological Reviews, vol. 92, no. 2, pp. 791-896, 2012.

[13] B. D. Paul and S. H. Snyder, " $\mathrm{H}_{2} \mathrm{~S}$ signalling through protein sulfhydration and beyond," Nature Reviews Molecular Cell Biology, vol. 13, no. 8, pp. 499-507, 2012.

[14] Y. Liu, R. Yang, X. Liu et al., "Hydrogen sulfide maintains mesenchymal stem cell function and bone homeostasis via regulation of $\mathrm{Ca}^{2+}$ channel sulfhydration," Cell Stem Cell, vol. 15, no. 1, pp. 66-78, 2014.

[15] O. Kabil and R. Banerjee, "Redox biochemistry of hydrogen sulfide," The Journal of Biological Chemistry, vol. 285, no. 29, pp. 21903-21907, 2010.

[16] X. Shen, M. Carlstrom, S. Borniquel, C. Jadert, C. G. Kevil, and J. O. Lundberg, "Microbial regulation of host hydrogen sulfide bioavailability and metabolism," Free Radical Biology \& Medicine, vol. 60, pp. 195-200, 2013.

[17] M. Whiteman, S. Le Trionnaire, M. Chopra, B. Fox, and J. Whatmore, "Emerging role of hydrogen sulfide in health and disease: critical appraisal of biomarkers and pharmacological tools," Clinical Science, vol. 121, no. 11, pp. 459-488, 2011.

[18] M. M. Kuo, D. H. Kim, S. Jandu et al., "MPST but not CSE is the primary regulator of hydrogen sulfide production and function in the coronary artery," American Journal of Physiology-Heart and Circulatory Physiology, vol. 310, no. 1, pp. H71-H79, 2016.
[19] K. Kashfi, R. Kodela, N. Nath, M. Chattopadhyay, D. E. Nesbitt, and C. A. Velázquez-Martínez, "Hydrogen sulfide-releasing naproxen suppresses colon cancer cell growth and inhibits NF- $\kappa \mathrm{B}$ signaling," Drug Design, Development and Therapy, vol. 9, article 4873, 2015.

[20] M. R. Hellmich and C. Szabo, "Hydrogen sulfide and cancer," Handbook of Experimental Pharmacology, vol. 230, pp. 233241, 2015.

[21] H. Ahn, E. Lee, K. Kim, and C. Lee, "Effect of glutathione and its related enzymes on chemosensitivity of renal cell carcinoma and bladder carcinoma cell lines," The Journal of Urology, vol. 151, no. 1, pp. 263-267, 1994.

[22] T. Simic, A. Savic-Radojevic, M. Pljesa-Ercegovac, M. Matic, and J. Mimic-Oka, "Glutathione S-transferases in kidney and urinary bladder tumors," Nature Reviews Urology, vol. 6, no. 5, pp. 281-289, 2009.

[23] A. Ianaro and G. Cirino, "Hydrogen sulfide pathway and cancer," Brain Metastases from Primary Tumors, Volume 3, vol. 3, pp. 133-144, 2016.

[24] C. Coletta, A. Papapetropoulos, K. Erdelyi et al., "Hydrogen sulfide and nitric oxide are mutually dependent in the regulation of angiogenesis and endothelium-dependent vasorelaxation," Proceedings of the National Academy of Sciences of the United States of America, vol. 109, no. 23, pp. 91619166, 2012.

[25] E. Pupo, A. Fiorio Pla, D. Avanzato et al., "Hydrogen sulfide promotes calcium signals and migration in tumor-derived endothelial cells," Free Radical Biology and Medicine, vol. 51, no. 9, pp. 1765-1773, 2011.

[26] S. L. Davis, P. J. Fadel, J. Cui, G. D. Thomas, and C. G. Crandall, "Skin blood flow influences near-infrared spectroscopyderived measurements of tissue oxygenation during heat stress," Journal of Applied Physiology, vol. 100, no. 1, pp. 221-224, 2006.

[27] W.-J. Cai, M.-J. Wang, L.-H. Ju, C. Wang, and Y.-C. Zhu, "Hydrogen sulfide induces human colon cancer cell proliferation: role of Akt, ERK and p21," Cell Biology International, vol. 34, no. 6, pp. 565-572, 2010.

[28] G. A. Bellingham, R. S. Smith, P. Morley-Forster, and J. M. Murkin, "Use of near infrared spectroscopy to detect impaired tissue oxygen saturation in patients with complex regional pain syndrome type 1 ," Canadian Journal of Anaesthesia, vol. 61, no. 6, pp. 563-570, 2014.

[29] Q. Cao, L. Zhang, G. Yang, C. Xu, and R. Wang, "Butyratestimulated $\mathrm{H}_{2} \mathrm{~S}$ production in colon cancer cells," Antioxidants \& Redox Signaling, vol. 12, no. 9, pp. 1101-1109, 2010.

[30] Y. Kimura, Y.-I. Goto, and H. Kimura, "Hydrogen sulfide increases glutathione production and suppresses oxidative stress in mitochondria," Antioxidants \& Redox Signaling, vol. 12, no. 1, pp. 1-13, 2010.

[31] G. Yang, L. Wu, B. Jiang et al., " $\mathrm{H}_{2} \mathrm{~S}$ as a physiologic vasorelaxant: hypertension in mice with deletion of Cystathionine $\gamma$-Lyase," Science, vol. 322, no. 5901, pp. 587-590, 2008.

[32] D. K. Ma, R. Vozdek, N. Bhatla, and H. R. Horvitz, "CYSL-1 Interacts with the $\mathrm{O}_{2}$-Sensing Hydroxylase EGL-9 to Promote $\mathrm{H}_{2} \mathrm{~S}$-Modulated Hypoxia-Induced Behavioral Plasticity in C. elegans," Neuron, vol. 73, no. 5, pp. 925-940, 2012.

[33] M. Bhatia, "Hydrogen sulfide and substance P in inflammation," Antioxidants \& Redox Signaling, vol. 12, no. 10, pp. 1191-1202, 2010. 
[34] R. Xue, D.-D. Hao, J.-P. Sun et al., "Hydrogen sulfide treatment promotes glucose uptake by increasing insulin receptor sensitivity and ameliorates kidney lesions in type 2 diabetes," Antioxidants \& Redox Signaling, vol. 19, no. 1, pp. 5-23, 2013.

[35] C. T. Yang, L. Chen, S. Xu, J. J. Day, X. Li, and M. Xian, "Recent development of hydrogen sulfide releasing/stimulating reagents and their potential applications in cancer and glycometabolic disorders," Frontiers in Pharmacology, vol. 8, 2017.

[36] M. Fu, W. Zhang, L. Wu, G. Yang, H. Li, and R. Wang, "Hydrogen sulfide $\left(\mathrm{H}_{2} \mathrm{~S}\right)$ metabolism in mitochondria and its regulatory role in energy production," Proceedings of the National Academy of Sciences of the United States of America, vol. 109, no. 8, pp. 2943-2948, 2012.

[37] I. Lobb, M. Davison, D. Carter et al., "Hydrogen sulfide treatment mitigates renal allograft ischemia-reperfusion injury during cold storage and improves early transplant kidney function and survival following allogeneic renal transplantation," The Journal of Urology, vol. 194, no. 6, pp. 18061815,2015

[38] G.-D. Yang and R. Wang, " $\mathrm{H}(2) \mathrm{S}$ and cellular proliferation and apoptosis," Sheng Li Xue Bao, vol. 59, no. 2, pp. 133$140,2007$.

[39] C. Szabó, "Hydrogen sulphide and its therapeutic potential," Nature Reviews Drug Discovery, vol. 6, no. 11, pp. 917-935, 2007.

[40] R. Guo, J. Lin, W. Xu et al., "Hydrogen sulfide attenuates doxorubicin-induced cardiotoxicity by inhibition of the p38 MAPK pathway in $\mathrm{H} 9 \mathrm{c} 2$ cells," International Journal of Molecular Medicine, vol. 31, no. 3, pp. 644-650, 2013.

[41] J. Du, Y. Huang, H. Yan et al., "Hydrogen sulfide suppresses oxidized low-density lipoprotein (Ox-LDL)-stimulated monocyte chemoattractant protein 1 generation from macrophages via the nuclear factor $\kappa \mathrm{B}(\mathrm{NF}-\kappa \mathrm{B})$ pathway," The Journal of Biological Chemistry, vol. 289, no. 14, pp. 9741-9753, 2014.

[42] E. Panza, P. de Cicco, C. Armogida et al., "Role of the cystathionine $\gamma$ lyase/hydrogen sulfide pathway in human melanoma progression," Pigment Cell \& Melanoma Research, vol. 28, no. 1, pp. 61-72, 2015.

[43] N. L. Whitfield, E. L. Kreimier, F. C. Verdial, N. Skovgaard, and K. R. Olson, "Reappraisal of $\mathrm{H}_{2} \mathrm{~S}$ /sulfide concentration in vertebrate blood and its potential significance in ischemic preconditioning and vascular signaling," American Journal of Physiology-Regulatory, Integrative and Comparative Physiology, vol. 294, no. 6, pp. R1930-R1937, 2008.

[44] M. Whiteman and P. K. Moore, "Hydrogen sulfide and the vasculature: a novel vasculoprotective entity and regulator of nitric oxide bioavailability?," Journal of Cellular and Molecular Medicine, vol. 13, no. 3, pp. 488-507, 2009.

[45] M. Ishigami, K. Hiraki, K. Umemura, Y. Ogasawara, K. Ishii, and H. Kimura, "A source of hydrogen sulfide and a mechanism of its release in the brain," Antioxidants \& Redox Signaling, vol. 11, no. 2, pp. 205-214, 2009.

[46] M. D. Levitt, M. S. Abdel-Rehim, and J. Furne, "Free and acid-labile hydrogen sulfide concentrations in mouse tissues: anomalously high free hydrogen sulfide in aortic tissue," Antioxidants \& Redox Signaling, vol. 15, no. 2, pp. 373-378, 2011.

[47] C. E. Cooper and G. C. Brown, "The inhibition of mitochondrial cytochrome oxidase by the gases carbon monoxide, nitric oxide, hydrogen cyanide and hydrogen sulfide: chemical mechanism and physiological significance," Journal of Bioenergetics and Biomembranes, vol. 40, no. 5, pp. 533539, 2008

[48] R. Baskar and J. Bian, "Hydrogen sulfide gas has cell growth regulatory role," European Journal of Pharmacology, vol. 656, no. 1-3, pp. 5-9, 2011.

[49] C. Szabo, C. Coletta, C. Chao et al., "Tumor-derived hydrogen sulfide, produced by cystathionine- $\beta$-synthase, stimulates bioenergetics, cell proliferation, and angiogenesis in colon cancer," Proceedings of the National Academy of Sciences of the United States of America, vol. 110, no. 30, pp. 12474-12479, 2013.

[50] T. M. Hildebrandt and M. K. Grieshaber, "Three enzymatic activities catalyze the oxidation of sulfide to thiosulfate in mammalian and invertebrate mitochondria," The FEBS Journal, vol. 275, no. 13, pp. 3352-3361, 2008.

[51] K. Kashfi and K. R. Olson, "Biology and therapeutic potential of hydrogen sulfide and hydrogen sulfide-releasing chimeras," Biochemical Pharmacology, vol. 85, no. 5, pp. 689703, 2013.

[52] M. R. Jackson, S. L. Melideo, and M. S. Jorns, "Human sulfide:quinone oxidoreductase catalyzes the first step in hydrogen sulfide metabolism and produces a sulfane sulfur metabolite," Biochemistry, vol. 51, no. 34, pp. 6804-6815, 2012.

[53] E. Lagoutte, S. Mimoun, M. Andriamihaja, C. Chaumontet, F. Blachier, and F. Bouillaud, "Oxidation of hydrogen sulfide remains a priority in mammalian cells and causes reverse electron transfer in colonocytes," Biochimica et Biophysica Acta (BBA) - Bioenergetics, vol. 1797, no. 8, pp. 1500-1511, 2010.

[54] K. R. Olson, "Hydrogen sulfide as an oxygen sensor," Antioxidants \& Redox Signaling, vol. 22, no. 5, pp. 377-397, 2015.

[55] A. K. Mustafa, M. M. Gadalla, N. Sen et al., " $\mathrm{H}_{2} \mathrm{~S}$ signals through protein S-sulfhydration," Science Signaling, vol. 2, no. 96, article ra72, 2009.

[56] N. Sen, B. D. Paul, M. M. Gadalla et al., "Hydrogen sulfide-linked sulfhydration of NF- $\kappa \mathrm{B}$ mediates its antiapoptotic actions," Molecular Cell, vol. 45, no. 1, pp. 13-24, 2012.

[57] C. Szabó and A. Papapetropoulos, "Hydrogen sulphide and angiogenesis: mechanisms and applications," British Journal of Pharmacology, vol. 164, no. 3, pp. 853-865, 2011.

[58] M. D. Levitt, J. Furne, J. Springfield, F. Suarez, and E. DeMaster, "Detoxification of hydrogen sulfide and methanethiol in the cecal mucosa," The Journal of Clinical Investigation, vol. 104, no. 8, pp. 1107-1114, 1999.

[59] R. A. Weisiger, L. M. Pinkus, and W. B. Jakoby, "Thiol Smethyltransferase: suggested role in detoxication of intestinal hydrogen sulfide," Biochemical Pharmacology, vol. 29, no. 20, pp. 2885-2887, 1980.

[60] D. J. Polhemus and D. J. Lefer, "Emergence of hydrogen sulfide as an endogenous gaseous signaling molecule in cardiovascular disease," Circulation Research, vol. 114, no. 4, pp. 730-737, 2014.

[61] M. Kajimura, R. Fukuda, R. M. Bateman, T. Yamamoto, and M. Suematsu, "Interactions of multiple gas-transducing systems: hallmarks and uncertainties of $\mathrm{CO}, \mathrm{NO}$, and $\mathrm{H}_{2} \mathrm{~S}$ gas biology," Antioxidants \& Redox Signaling, vol. 13, no. 2, pp. 157-192, 2010. 
[62] V. Vitvitsky, P. K. Yadav, S. An, J. Seravalli, U.-S. Cho, and R. Banerjee, "Structural and mechanistic insights into hemoglobin-catalyzed hydrogen sulfide oxidation and the fate of polysulfide products," The Journal of Biological Chemistry, vol. 292, no. 13, pp. 5584-5592, 2017.

[63] L. Zhang, Q. Qi, J. Yang et al., "An anticancer role of hydrogen sulfide in human gastric cancer cells," Oxidative Medicine and Cellular Longevity, vol. 2015, Article ID 636410, 8 pages, 2015.

[64] M. Lv, Y. Li, M.-H. Ji, M. Zhuang, and J.-H. Tang, "Inhibition of invasion and epithelial-mesenchymal transition of human breast cancer cells by hydrogen sulfide through decreased phospho-p38 expression," Molecular Medicine Reports, vol. 10, no. 1, pp. 341-346, 2014.

[65] M. R. Hellmich, C. Coletta, C. Chao, and C. Szabo, "The therapeutic potential of cystathionine $\beta$-synthetase/hydrogen sulfide inhibition in cancer," Antioxidants \& Redox Signaling, vol. 22, no. 5, pp. 424-448, 2015.

[66] X. Cao, L. Ding, Z. Xie et al., "A review of hydrogen sulfide synthesis, metabolism, and measurement: is modulation of hydrogen sulfide a novel therapeutic for cancer?," Antioxidants \& Redox Signaling, vol. 31, no. 1, pp. 1-38, 2019.

[67] D. Wu, W. Si, M. Wang, S. Lv, A. Ji, and Y. Li, "Hydrogen sulfide in cancer: friend or foe?," Nitric Oxide, vol. 50, pp. 38-45, 2015.

[68] M. A. Kaium, Y. Liu, Q. Zhu et al., " $\mathrm{H}_{2} \mathrm{~S}$ donor, S-propargylcysteine, increases CSE in SGC-7901 and cancer-induced mice: evidence for a novel anti-cancer effect of endogenous $\mathrm{H}_{2} \mathrm{~S}$ ?," PLoS One, vol. 6, no. 6, article e20525, 2011.

[69] S. Ramasamy, S. Singh, P. Taniere, M. J. S. Langman, and M. C. Eggo, "Sulfide-detoxifying enzymes in the human colon are decreased in cancer and upregulated in differentiation," American Journal of Physiology-Gastrointestinal and Liver Physiology, vol. 291, no. 2, pp. G288-G296, 2006.

[70] M. Chattopadhyay, R. Kodela, N. Nath, A. Barsegian, D. Boring, and K. Kashfi, "Hydrogen sulfide-releasing aspirin suppresses NF- $\kappa$ B signaling in estrogen receptor negative breast cancer cells in vitro and in vivo," Biochemical Pharmacology, vol. 83, no. 6, pp. 723-732, 2012.

[71] S. Bhattacharyya, S. Saha, K. Giri et al., "Cystathionine betasynthase (CBS) contributes to advanced ovarian cancer progression and drug resistance," PLoS One, vol. 8, no. 11, article e79167, 2013.

[72] K. Módis, C. Coletta, A. Asimakopoulou et al., "Effect of Sadenosyl-1-methionine (SAM), an allosteric activator of cystathionine- $\beta$-synthase (CBS) on colorectal cancer cell proliferation and bioenergetics in vitro," Nitric Oxide, vol. 41, pp. 146-156, 2014.

[73] B. Szczesny, M. Marcatti, J. R. Zatarain et al., "Inhibition of hydrogen sulfide biosynthesis sensitizes lung adenocarcinoma to chemotherapeutic drugs by inhibiting mitochondrial DNA repair and suppressing cellular bioenergetics," Scientific Reports, vol. 6, no. 1, 2016.

[74] A. T. Meram, J. Chen, S. Patel et al., "Hydrogen sulfide is increased in oral squamous cell carcinoma compared to adjacent benign oral mucosae," Anticancer Research, vol. 38, no. 7, pp. 3843-3852, 2018.

[75] Z.-W. Lee, X.-Y. Teo, E. Y.-W. Tay et al., "Utilizing hydrogen sulfide as a novel anti-cancer agent by targeting cancer glycolysis and $\mathrm{pH}$ imbalance," British Journal of Pharmacology, vol. 171, no. 18, pp. 4322-4336, 2014.
[76] Z. Ma, Q. Bi, and Y. Wang, "Hydrogen sulfide accelerates cell cycle progression in oral squamous cell carcinoma cell lines," Oral Diseases, vol. 21, no. 2, pp. 156-162, 2015.

[77] C. Szabo and M. R. Hellmich, "Endogenously produced hydrogen sulfide supports tumor cell growth and proliferation," Cell Cycle, vol. 12, no. 18, pp. 2915-2916, 2014.

[78] B. Renga, "Hydrogen sulfide generation in mammals: the molecular biology of cystathionine- $\beta$-synthase (CBS) and cystathionine- $\gamma$-lyase (CSE)," Inflammation \& Allergy - Drug Targets, vol. 10, no. 2, pp. 85-91, 2011.

[79] E. Sonke, M. Verrydt, C. O. Postenka et al., "Inhibition of endogenous hydrogen sulfide production in clear-cell renal cell carcinoma cell lines and xenografts restricts their growth, survival and angiogenic potential," Nitric Oxide, vol. 49, pp. 26-39, 2015.

[80] H. Jurkowska, W. Placha, N. Nagahara, and M. Wróbel, "The expression and activity of cystathionine- $\gamma$-lyase and 3mercaptopyruvate sulfurtransferase in human neoplastic cell lines," Amino Acids, vol. 41, no. 1, pp. 151-158, 2011.

[81] A. A. Untereiner, A. Pavlidou, N. Druzhyna, A. Papapetropoulos, M. R. Hellmich, and C. Szabo, "Drug resistance induces the upregulation of $\mathrm{H}_{2} \mathrm{~S}$-producing enzymes in HCT116 colon cancer cells," Biochemical Pharmacology, vol. 149, pp. 174-185, 2018.

[82] M. Chattopadhyay, N. Nath, R. Kodela et al., "Hydrogen sulfide-releasing aspirin inhibits the growth of leukemic Jurkat cells and modulates $\beta$-catenin expression," Leukemia Research, vol. 37, no. 10, pp. 1302-1308, 2013.

[83] M. Chattopadhyay, R. Kodela, N. Nath et al., "Hydrogen sulfide-releasing NSAIDs inhibit the growth of human cancer cells: a general property and evidence of a tissue typeindependent effect," Biochemical Pharmacology, vol. 83, no. 6, pp. 715-722, 2012.

[84] C. Zhang, Q.-Z. Zhang, K. Zhang et al., "Dual-biomarkertriggered fluorescence probes for differentiating cancer cells and revealing synergistic antioxidant effects under oxidative stress," Chemical Science, vol. 10, no. 7, pp. 1945-1952, 2019.

[85] K. Zhang, J. Zhang, Z. Xi et al., "A new H2S-specific nearinfrared fluorescence-enhanced probe that can visualize the $\mathrm{H}_{2} \mathrm{~S}$ level in colorectal cancer cells in mice," Chemical Science, vol. 8, no. 4, pp. 2776-2781, 2017.

[86] P. Rose, "Hydrogen sulfide protects colon cancer cells from chemopreventative agent $\beta$-phenylethyl isothiocyanate induced apoptosis," World Journal of Gastroenterology, vol. 11, no. 26, pp. 3990-3997, 2005.

[87] D. Wu, M. Li, W. Tian et al., "Hydrogen sulfide acts as a double-edged sword in human hepatocellular carcinoma cells through EGFR/ERK/MMP-2 and PTEN/AKT signaling pathways," Scientific Reports, vol. 7, 2017.

[88] B. Muz, P. de la Puente, F. Azab, and A. K. Azab, "The role of hypoxia in cancer progression, angiogenesis, metastasis, and resistance to therapy," Hypoxia, vol. 3, pp. 83-92, 2015.

[89] N. Takano, Y.-J. Peng, G. K. Kumar et al., "Hypoxia-inducible factors regulate human and rat cystathionine $\beta$-synthase gene expression," The Biochemical Journal, vol. 458, no. 2, pp. 203-211, 2014.

[90] M. Wang, Z. Guo, and S. Wang, "Regulation of cystathionine $\gamma$-lyase in mammalian cells by hypoxia," Biochemical Genetics, vol. 52, no. 1-2, pp. 29-37, 2014.

[91] B. Wu, H. Teng, L. Zhang et al., "Interaction of hydrogen sulfide with oxygen sensing under hypoxia," Oxidative Medicine 
and Cellular Longevity, vol. 2015, Article ID 758678, 9 pages, 2015.

[92] F. Malagrinò, K. Zuhra, L. Mascolo et al., "Hydrogen sulfide oxidation: adaptive changes in mitochondria of SW480 colorectal cancer cells upon exposure to hypoxia," Oxidative Medicine and Cellular Longevity, vol. 2019, Article ID 8102936, 11 pages, 2019.

[93] V. Vitvitsky, O. Kabil, and R. Banerjee, "High turnover rates for hydrogen sulfide allow for rapid regulation of its tissue concentrations," Antioxidants \& Redox Signaling, vol. 17, no. 1, pp. 22-31, 2012.

[94] S. Sen, B. Kawahara, D. Gupta et al., "Role of cystathionine $\beta$-synthase in human breast cancer," Free Radical Biology and Medicine, vol. 86, pp. 228-238, 2015.

[95] R. E. Shackelford, J. Abdulsattar, E. X. Wei, J. Cotelingam, D. Coppola, and G. A. Herrera, "Increased nicotinamide phosphoribosyltransferase and Cystathionine- $\beta$-Synthase in renal oncocytomas, renal urothelial carcinoma, and renal clear cell carcinoma," Anticancer Research, vol. 37, no. 7, pp. 3423-3427, 2017.

[96] J. Ferlay, I. Soerjomataram, R. Dikshit et al., "Cancer incidence and mortality worldwide: sources, methods and major patterns in GLOBOCAN 2012," International Journal of Cancer, vol. 136, no. 5, pp. E359-E386, 2015.

[97] R. L. Siegel, K. D. Miller, and A. Jemal, "Cancer statistics, 2019," CA: A Cancer Journal for Clinicians, vol. 69, no. 1, pp. 7-34, 2018.

[98] V. Margulis, S. F. Shariat, S. F. Matin et al., "Outcomes of radical nephroureterectomy: a series from the Upper Tract Urothelial Carcinoma Collaboration," Cancer, vol. 115, no. 6, pp. 1224-1233, 2009.

[99] S. R. Krishna and B. R. Konety, "Current concepts in the management of muscle invasive bladder cancer," Indian Journal of Surgical Oncology, vol. 8, no. 1, pp. 74-81, 2017.

[100] X. Zhang, C. Han, and J. He, "Recent advances in the diagnosis and management of bladder cancer," Cell Biochemistry and Biophysics, vol. 73, no. 1, pp. 11-15, 2015.

[101] A. Althunayan and W. Kassouf, "Asymptomatic microscopic hematuria: clinical significance and evaluation," Current Medical Literature, vol. 17, 2011.

[102] H. Wallerand, R. R. Reiter, and A. Ravaud, "Molecular targeting in the treatment of either advanced or metastatic bladder cancer or both according to the signalling pathways," Current Opinion in Urology, vol. 18, no. 5, pp. 524-532, 2008.

[103] C.-J. Chung, Y.-S. Pu, C.-T. Su et al., "Polymorphisms in onecarbon metabolism pathway genes, urinary arsenic profile, and urothelial carcinoma," Cancer Causes \& Control, vol. 21, no. 10, pp. 1605-1613, 2010.

[104] L. E. Moore, N. Malats, N. Rothman et al., "Polymorphisms in one-carbon metabolism and trans-sulfuration pathway genes and susceptibility to bladder cancer," International Journal of Cancer, vol. 120, no. 11, pp. 2452-2458, 2007.

[105] R. A. Dombkowski, "Hydrogen sulfide mediates hypoxiainduced relaxation of trout urinary bladder smooth muscle," The Journal of Experimental Biology, vol. 209, no. 16, pp. 3234-3240, 2006.

[106] V. S. Fernandes, A. S. F. Ribeiro, M. V. Barahona et al., "Hydrogen sulfide mediated inhibitory neurotransmission to the pig bladder neck: role of $\mathrm{K}_{\mathrm{ATP}}$ channels, sensory nerves and calcium signaling," The Journal of Urology, vol. 190, no. 2, pp. 746-756, 2013.
[107] F. Fusco, R. d'Emmanuele di Villa Bianca, E. Mitidieri, G. Cirino, R. Sorrentino, and V. Mirone, "Sildenafil Effect on the human bladder involves the L-cysteine/hydrogen sulfide pathway: a novel mechanism of action of phosphodiesterase type 5 inhibitors," European Urology, vol. 62, no. 6, pp. 1174-1180, 2012.

[108] J.-W. Gai, W. Wahafu, H. Guo et al., "Further evidence of endogenous hydrogen sulphide as a mediator of relaxation in human and rat bladder," Asian Journal of Andrology, vol. 15 , no. 5, pp. 692-696, 2013.

[109] M. Matsunami, T. Miki, K. Nishiura et al., "Involvement of the endogenous hydrogen sulfide/ $\mathrm{Ca}_{\mathrm{v}} 3.2 \mathrm{~T}$-type $\mathrm{Ca}^{2+}$ channel pathway in cystitis-related bladder pain in mice," British Journal of Pharmacology, vol. 167, no. 4, pp. 917928, 2012.

[110] W. C. de Groat and N. Yoshimura, "Pharmacology of the lower urinary tract," Annual Review of Pharmacology and Toxicology, vol. 41, no. 1, pp. 691-721, 2001.

[111] J.-W. Gai, W. Qin, M. Liu et al., "Expression profile of hydrogen sulfide and its synthases correlates with tumor stage and grade in urothelial cell carcinoma of bladder," Urologic Oncology: Seminars and Original Investigations, vol. 34, no. 4, pp. 166.e15-166.e20, 2016.

[112] W. Wahafu, J. Gai, L. Song et al., "Increased H2S and its synthases in urothelial cell carcinoma of the bladder, and enhanced cisplatin-induced apoptosis following H2S inhibition in EJ cells," Oncology Letters, vol. 15, 2018.

[113] H. Liu, J. Chang, Z. Zhao, Y. Li, and J. Hou, "Effects of exogenous hydrogen sulfide on the proliferation and invasion of human bladder cancer cells," Journal of Cancer Research and Therapeutics, vol. 13, no. 5, pp. 829-832, 2017.

[114] R. E. Shackelford, K. Mayhall, N. M. Maxwell, E. Kandil, and D. Coppola, "Nicotinamide phosphoribosyltransferase in malignancy: a review," Genes \& Cancer, vol. 4, no. 11-12, pp. 447-456, 2013.

[115] R. Sanokawa-Akakura, E. A. Ostrakhovitch, S. Akakura, S. Goodwin, and S. Tabibzadeh, "A $\mathrm{H}_{2} \mathrm{~S}$-Nampt dependent energetic circuit is critical to survival and cytoprotection from damage in cancer cells," PLoS One, vol. 9, no. 9, article e108537, 2014.

[116] U. Capitanio, K. Bensalah, A. Bex et al., "Epidemiology of renal cell carcinoma," European Urology, vol. 75, no. 1, pp. 74-84, 2019.

[117] G. Kovacs, M. Akhtar, B. J. Beckwith et al., "The Heidelberg classification of renal cell tumours," The Journal of Pathology, vol. 183, no. 2, pp. 131-133, 1997.

[118] K. P. van Houwelingen, B. A. C. van Dijk, C. A. Hulsbergen-van de Kaa et al., "Prevalence of von Hippel-Lindau gene mutations in sporadic renal cell carcinoma: results from the Netherlands cohort study," BMC Cancer, vol. 5, no. 1, 2005

[119] B. I. Rini, S. C. Campbell, and B. Escudier, "Renal cell carcinoma," The Lancet, vol. 373, no. 9669, pp. 1119-1132, 2009.

[120] R. J. Motzer and P. Russo, "Systemic therapy for renal cell carcinoma," The Journal of Urology, vol. 163, no. 2, pp. 408-417, 2000.

[121] J. Breza, A. Soltysova, S. Hudecova et al., "Endogenous $\mathrm{H}_{2} \mathrm{~S}$ producing enzymes are involved in apoptosis induction in clear cell renal cell carcinoma," BMC Cancer, vol. 18, 2018.

[122] F. Audenet, D. R. Yates, G. Cancel-Tassin, O. Cussenot, and M. Rouprêt, "Genetic pathways involved in carcinogenesis 
of clear cell renal cell carcinoma: genomics towards personalized medicine," BJU International, vol. 109, no. 12, pp. 18641870, 2012.

[123] P. H. Maxwell, M. S. Wiesener, G.-W. Chang et al., "The tumour suppressor protein VHL targets hypoxia-inducible factors for oxygen-dependent proteolysis," Nature, vol. 399, no. 6733, pp. 271-275, 1999.

[124] A. Schulze and A. L. Harris, "How cancer metabolism is tuned for proliferation and vulnerable to disruption," Nature, vol. 491, no. 7424, pp. 364-373, 2012.

[125] X. Chen, Y. Qian, and S. Wu, “The Warburg effect: evolving interpretations of an established concept," Free Radical Biology \& Medicine, vol. 79, pp. 253-263, 2015.

[126] P. De Cicco, E. Panza, G. Ercolano et al., "ATB-346, a novel hydrogen sulfide-releasing anti-inflammatory drug, induces apoptosis of human melanoma cells and inhibits melanoma development in vivo," Pharmacological Research, vol. 114, pp. 67-73, 2016.

[127] L. Lencesova, M. Vlcek, O. Krizanova, and S. Hudecova, "Hypoxic conditions increases $\mathrm{H}_{2} \mathrm{~S}$-induced ER stress in A2870 cells," Molecular and Cellular Biochemistry, vol. 414, no. 1-2, pp. 67-76, 2016.

[128] S. Lu, L. Chen, Q. Huang et al., "Decomposition of ammonia and hydrogen sulfide in simulated sludge drying waste gas by a novel non-thermal plasma," Chemosphere, vol. 117, pp. 781-785, 2014.

[129] J. Markova, S. Hudecova, A. Soltysova et al., "Sodium/calcium exchanger is upregulated by sulfide signaling, forms complex with the $\beta 1$ and $\beta 3$ but not $\beta 2$ adrenergic receptors, and induces apoptosis," Pflügers Archiv - European Journal of Physiology, vol. 466, no. 7, pp. 1329-1342, 2014.

[130] A. Misak, M. Grman, Z. Bacova et al., "Polysulfides and products of $\mathrm{H}_{2} \mathrm{~S} / \mathrm{S}$-nitrosoglutathione in comparison to $\mathrm{H}_{2} \mathrm{~S}$, glutathione and antioxidant Trolox are potent scavengers of superoxide anion radical and produce hydroxyl radical by decomposition of $\mathrm{H}_{2} \mathrm{O}_{2}$," Nitric Oxide, vol. 76, pp. 136-151, 2018.

[131] F. Cappello, E. Conway de Macario, L. Marasà, G. Zummo, and A. J. L. Macario, "Hsp60 expression, new locations, functions, and perspectives for cancer diagnosis and therapy," Cancer Biology \& Therapy, vol. 7, no. 6, pp. 801-809, 2008.

[132] J. C. Ghosh, T. Dohi, B. H. Kang, and D. C. Altieri, "Hsp60 regulation of tumor cell apoptosis," The Journal of Biological Chemistry, vol. 283, no. 8, pp. 5188-5194, 2008.

[133] Y.-P. Tsai, M.-H. Yang, C.-H. Huang et al., "Interaction between HSP60 and $\beta$-catenin promotes metastasis," Carcinogenesis, vol. 30, no. 6, pp. 1049-1057, 2009.

[134] H. Tang, Y. Chen, X. Liu et al., "Downregulation of HSP60 disrupts mitochondrial proteostasis to promote tumorigenesis and progression in clear cell renal cell carcinoma," Oncotarget, vol. 7, no. 25, 2016.

[135] Q. Dong, B. Yang, J.-G. Han et al., “A novel hydrogen sulfidereleasing donor, HA-ADT, suppresses the growth of human breast cancer cells through inhibiting the PI3K/AKT/mTOR and Ras/Raf/MEK/ERK signaling pathways," Cancer Letters, vol. 455 , pp. 60-72, 2019.

[136] H. Guo, P. German, S. Bai et al., "The PI3K/AKT pathway and renal cell carcinoma," Journal of Genetics and Genomics, vol. 42, no. 7, pp. 343-353, 2015.

[137] L. B. Valenca, C. J. Sweeney, and M. M. Pomerantz, "Sequencing current therapies in the treatment of metastatic prostate cancer," Cancer Treatment Reviews, vol. 41, no. 4, pp. 332-340, 2015.

[138] M. Liu, L. Wu, S. Montaut, and G. Yang, "Hydrogen sulfide signaling axis as a target for prostate cancer therapeutics," Prostate Cancer, vol. 2016, Article ID 8108549, 9 pages, 2016.

[139] H. Guo, J.-W. Gai, Y. Wang, H.-F. Jin, J.-B. Du, and J. Jin, "Characterization of hydrogen sulfide and its synthases, cystathionine $\beta$-synthase and cystathionine $\gamma$-lyase, in human prostatic tissue and cells," Urology, vol. 79, no. 2, pp. 483.e1-483.e5, 2012.

[140] K. Zhao, S. Li, L. Wu, C. Lai, and G. Yang, "Hydrogen sulfide represses androgen receptor transactivation by targeting at the second zinc finger module," The Journal of Biological Chemistry, vol. 289, no. 30, pp. 20824-20835, 2014.

[141] E. Bigagli, C. Luceri, M. de Angioletti et al., "New NO- and $\mathrm{H}_{2} \mathrm{~S}$-releasing doxorubicins as targeted therapy against chemoresistance in castration-resistant prostate cancer: in vitro and in vivo evaluations," Investigational New Drugs, vol. 36, no. 6, pp. 985-998, 2018.

[142] Y. Pei, B. Wu, Q. Cao, L. Wu, and G. Yang, "Hydrogen sulfide mediates the anti-survival effect of sulforaphane on human prostate cancer cells," Toxicology and Applied Pharmacology, vol. 257, no. 3, pp. 420-428, 2011.

[143] G. Chwatko, E. Forma, J. Wilkosz et al., "Thiosulfate in urine as a facilitator in the diagnosis of prostate cancer for patients with prostate-specific antigen less or equal $10 \mathrm{ng} / \mathrm{mL}$," Clinical Chemistry and Laboratory Medicine, vol. 51, no. 9, pp. 1825-1831, 2013.

[144] F. Al-Awadi, M. Yang, Y. Tan, Q. Han, S. Li, and R. M. Hoffman, "Human tumor growth in nude mice is associated with decreased plasma cysteine and homocysteine," Anticancer Research, vol. 28, no. 5A, pp. 2541-2544, 2008.

[145] W. Zhang, A. Braun, Z. Bauman, H. Olteanu, P. Madzelan, and R. Banerjee, "Expression profiling of homocysteine junction enzymes in the NCI60 panel of human cancer cell lines," Cancer Research, vol. 65, no. 4, pp. 1554-1560, 2005.

[146] F. Kimura, K. H. Franke, C. Steinhoff et al., "Methyl group metabolism gene polymorphisms and susceptibility to prostatic carcinoma," The Prostate, vol. 45, no. 3, pp. 225-231, 2000.

[147] S. Stabler, T. Koyama, Z. Zhao et al., "Serum methionine metabolites are risk factors for metastatic prostate cancer progression," PLoS One, vol. 6, no. 8, article e22486, 2011.

[148] C. Stephan, K. Jung, K. Miller, and B. Ralla, "New biomarkers in serum and urine for detection of prostate cancer," Aktuelle Urologie, vol. 46, no. 2, pp. 129-143, 2015.

[149] P. D. Deeble, M. E. Cox, H. F. Frierson Jr. et al., “Androgenindependent growth and tumorigenesis of prostate cancer cells are enhanced by the presence of PKA-differentiated neuroendocrine cells," Cancer Research, vol. 67, no. 8, pp. $3663-$ 3672, 2007.

[150] A. Komiya, H. Suzuki, T. Imamoto et al., "Neuroendocrine differentiation in the progression of prostate cancer," International Journal of Urology, vol. 16, no. 1, pp. 37-44, 2009.

[151] J. H. Heo, H. N. Seo, Y. J. Choe et al., "T-type $\mathrm{Ca}^{2+}$ channel blockers suppress the growth of human cancer cells," Bioorganic \& Medicinal Chemistry Letters, vol. 18, no. 14, pp. 3899-3901, 2008. 


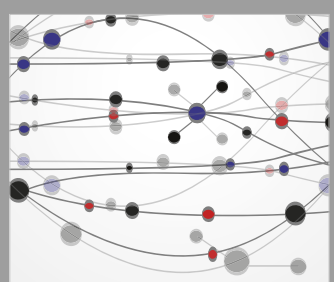

The Scientific World Journal
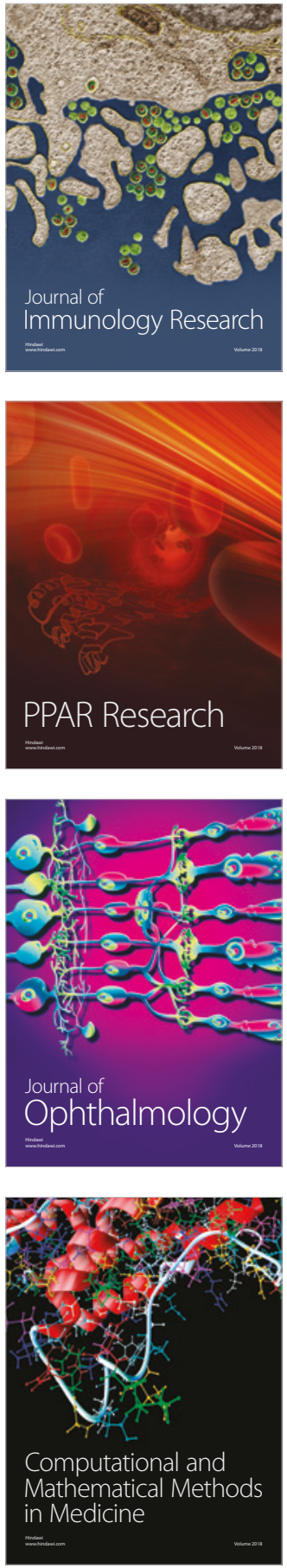

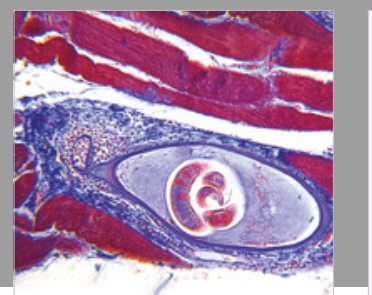

Gastroenterology Research and Practice



\section{Hindawi}

Submit your manuscripts at

www.hindawi.com


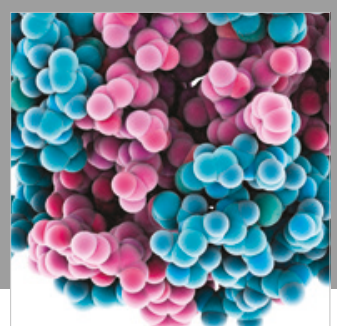

ournal of

Diabetes Research

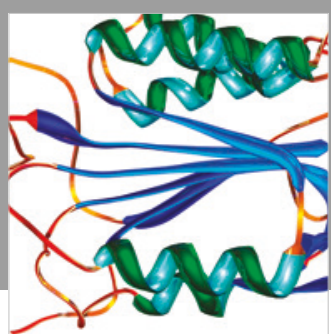

Disease Markers
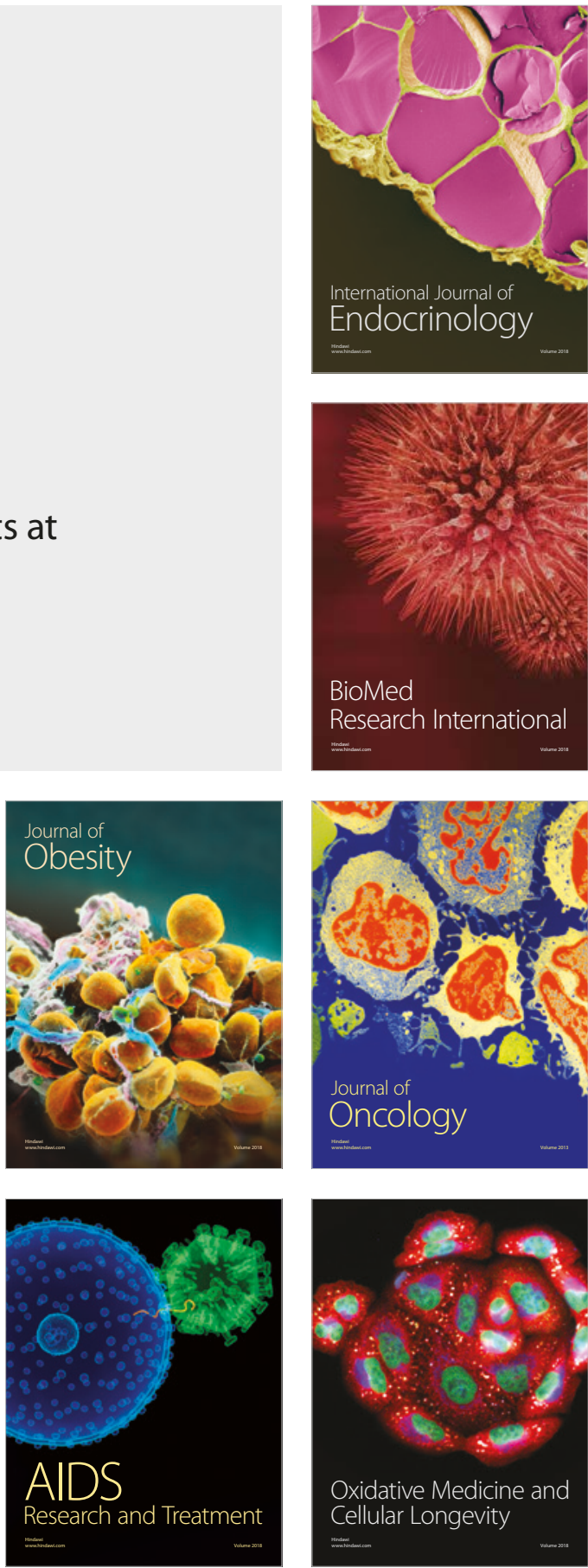